WIELKIE TEMATY KULTURY W LITERATURACH SŁOWIAŃSKICH

Slavica Wratislaviensia CLXVIII • Wrocław 2019•AUWr No 3875

DOI: 10.19195/0137-1150.168.30

Data przesłania artykułu: 24.09 .2017

Data akceptacji artykułu: 8.01.2018

\author{
LUBOMÍR MACHALA
}

Univerzita Palackého v Olomouci, Republika Czeska

\title{
Souboje a tance se smrtí v zrcadle nesmrtelnosti (z české a slovenské polistopadové prózy)
}

Tematizace odvěkého traumatu lidské smrtelnosti, poprrípadě snahy anulovat ho představami o nesmrtelnosti, stejně jako traktování nejrůznějších podob konce bytí byly v českých a slovenských prózách publikovaných premiérově po listopadu 1989 vskutku frekventovanými jevy. Základním cílem mého příspěvku bude alespoň přibližně demonstrovat připomínkou konkrétních děl četnost tohoto tematologického fenoménu a postihnout také jeho typologickou pestrost. V neposlední řadě se ve vybraných prŕpadech ${ }^{1}$ pokusím analyticko-interpretačním výkladem přiblížit také jejich osobitost či specifický př́nos jak v tanatologických souvislostech, tak v hodnotových hierarchiích obou zmíněných národních literatur.

V českých prózách vydávaných počátkem 90 . let 20 . století nelze přehlédnout výraznou emancipaci vypravěčủ. Vypravěč (nezřídka vybavený autobiografickými rysy) ostentativně zaujímá centrální pozici, funguje jako stvořitel a verifikátor. Jeho demiurgovská podstata se projevuje i v pojímání ostatních postav jako jím ovládaných loutek nebo v nabízení různých řešení př́íběhu. Výsostná vypravěčská pozice pak dovoluje rozehrávat i mnohé hry, a to v různých úrovních a podobách: jazykové, kompoziční, fabulační či sémantické; hry se čtenářem, s postavami, $\mathrm{s}$ vlastními i cizími texty, $\mathrm{s}$ tradicí, s časem.

K těm nejvyzývavějším patř́i hra (spíše zápas) se smrtí. Daniela Hodrová (narozena 1946) ve své trilogii Trýznivé město, kterou začala psát už koncem 70. let a která ovšem mohla být vydána až po listopadu 1989 (Podoboji 1991, Kukly 1991, Théta 1992, společně 1999), smrt všelijak zaříkává, postavy volně přechá-

\footnotetext{
${ }^{1}$ Hlavními kritérii výběru bude typologická reprezentativnost a umělecká přesvědčivost díla.
} 
zejí hranici mezi bytím a nebytím, mrtví komunikují s živými, autorka jako by čtenářům chtěla vsugerovat, že smrt je možné pokořit, poukazujíc na cykličnost a permanentnost veškerého dění: „,V tomhle světě nic nezaniká, jak říká na Olšanech pan Tureček. Všechno se jen neustále proměňuje“2, „tu existuje tajemný a osudový koloběh, jemuž vzdorovat je nesmyslné“"3. Hodrové texty mají blízko k mystice a ezoterice, čemuž odpovídá i její ztvárnění mortální tematiky.

Otevřený souboj se smrtí podstupují protagonisté knih Martina Komárka (narozen 1961) Dřevěná panenka (1990), Mefitis (1996) a Králiček vám dodá les$k u$ (1998). I když výsledek těchto střetnutí přes všechny naděje, a co kdyby, které v sobě chovají Komárkovy postavy (a nejen ony), je dopředu jasný, je též zřejmé, že nejde o souboje zbytečné, protože prrispívají k poznání, co je za života podstatné, a co nikoliv.

Téma nesmrtelnosti bylo před koncem 20. století v české literatuře mimořádně exponováno a představuje též součást tematického plánu prózy Petra Koudelky (narozen 1942) Peřička, peřička (1992). Autor v ní k nesmrtelnosti přistupuje v poněkud laboratorním nasvícení, jelikož normalizační dvacetiletí zpř́tomňuje prostřednictvím pokusu, při němž mozek hlavní postavy slouží tajné policii jako experimentální zdroj „zprávy o budovatelích komunismu v Československu ve dvaceti letech po srpnu 68.“4 . Podle oportunistického protagonisty je to: „zpráva o pravém stavu věcí, pravda o tom, jací jsme byli doopravdy, svědectví o naší rozpolcenosti “5. Vedle prezentace typické normalizační schizofrenie soukromých názorů a veřejného vystupování text poukazuje rovněž na různost rolí, které musí člověk v životě hrát. Hlavně však ústí v poznání:

Jediný pravý a skutečný život je vnitřní, tvůj duševní život. Vnější je nedůležitý, ba co víc, nereálný, neskutečný. Což není důkazem, že každá sebedrobnější událost je hodnocena každým jinak a že neexistují ani dva lidé, kteří by se shodli na jednom popisu a výkladu? ${ }^{6}$

Postmodernistickou multiperspektivitu a relativizaci hodnot sdílí Koudelkův román s jiným románem, který ovšem upoutal mnohem větší pozornost čtenářů i kritiků. Samožrejmě jde o Nesmrtelnost Milana Kundery (narozen 1929), takto poslední Kunderův román napsaný autorem v rodném jazyce, byt' francouzská podoba románu pod titulem L'Immortalité vyšla už v roce 1990, tedy o tři roky dříve než české vydání. Nesmrtelnost se mnohdy vrací k tématům, problémům i tvárným postupům z Kunderovy dřívější tvorby, přičemž je rozvíjí, variuje, syntetizuje. Také ústř̌ední téma nesmrtelnosti, respektive reflektování podmínek a možností, za nichž se může člověk stát takzvaně nesmrtelným (a co takový stav vlastně může obnášet), vychází v podstatě z návratu k Žertu (1967), konkrétně k úvahám o snaze každého člověka zanechat po sobě nějaký pomník, zřetelnou

\footnotetext{
2 D. Hodrová, Kukly, Praha 1991, s. 242.

${ }^{3}$ D. Hodrová, Podobojí, Praha 1991, s. 120.

${ }^{4}$ P. Koudelka, Peřička, peřička, Praha 1992, s. 38.

5 Ibidem, s. 26.

${ }^{6}$ Ibidem, s. 165.
} 
stopu. Zhuštěnou formulaci této touhy a usilování autor vložil v Nesmrtelnosti do úst mladé ženy Laury, která protagonistce románu Agnes v sesterské hádce ř́iká:

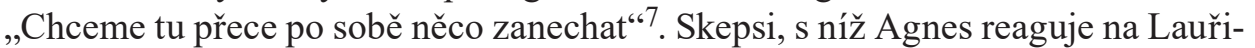
no přesvědčení, už známe ze Žertu, ale dotyčné téma je v Nesmrtelnosti rozvinuto o paradox, podle něhož stejně jako náš obraz, charakteristika osobnosti už za života není záležitostí sebereflexe, není v rukou nás samých, ale tvoří je názory, mínění okolí: „Pokud žijeme s lidmi, nejsme než to, za co nás lidé považuji‘‘8 A také naše odkazy, stopy, nejrůznější díla jsou vydány všanc druhým, jejich výkladům, manipulacím, představám. V románu Nesmrtelnost o svých zkušenostech s podobnými záležitostmi debatují Goethe s Hemingwayem, znechucení mimo jiné tím, že lidé se většinou ani nezajímají o tvůrčí pozůstalost (která bývá navíc redukována na několik zkomolených citátů), ale projeví-li vůbec nějaký zájem, pak tento směřuje $\mathrm{k}$ pikanteriím ze soukromého života, které se $\mathrm{v}$ př́ípadě jejich nedostatku i přimyslí.

Jak už dříve zmíněno, recenzní ohlas Kunderovy Nesmrtelnosti byl značný a dodejme - také různorodý až rozporuplný. $\mathrm{V}$ souvislosti s tématem příspěvku je pozoruhodné zvláště kritické vystoupení Karla Křepelky, rázně zavrhující Kunderovo dílo, a to hlavně pro údajný nedostatek jakékoliv spirituality, jakékoliv duchovnosti ${ }^{9}$. Ani další křest’ansky založení tvůrci nepřijali inkriminovaný román zrovna s nadšením ${ }^{10}$.

Podstatu jejich negativního přijetí vlastně předem postihla Sylvie Richterová v eseji Otázka Boha ve světě bez Boha publikovaném v „Literárních novinách“ už v roce 1991, tedy dva roky před českým vydáním Nesmrtelnosti. Richterová totiž mimo jiné poukázala na skutečnost, že na místě transcendentna Kundera nabízí v Nesmrtelnosti paradox nemající řešení v rámci daného románu, jazyka či systému: „,vrcholné naplnění lidské touhy vtisknout vlastní podobu nesmazatelně do mysli druhých lidí, fatálně přináší naprostou ztrátu vlastní podoby, její odcizení: «Nesmrtelná» postava je dílem druhých. Úplné dosažení cíle znamená jeho úplnou ztrátu“11. Pro věřícího člověka je rovněž těžko akceptovatelný i další paradox obsažený v Kunderově textu, jehož formulací Sylvie Richterová svou úvahu končí:

Nesmrtelnost je zbytnění obrazu člověka, planeta se řítí prázdnem. Nejvyšší soudce neexistuje. Hrdina Kunderových románů koncipuje svět a sebe jako uzavřený systém, mimo který neexistuje žádný prvek vymykající se celkové relativnosti věcí, a věnuje se nekonečnému reflektování sebe sama v nových a nových systémech zrcadel. Takto koncipovaný člověk

${ }^{7}$ M. Kundera, Nesmrtelnost, Brno 1993, s. 100.

${ }^{8}$ Ibidem, s. 131.

${ }^{9}$ K. Křepelka, Př́liš smrtelná nesmrtelnost, „Proglas“ 1993, č. 9-10 (4), s. 104-106.

${ }^{10}$ P. Švanda, Nesmrtelnost a nedůvěřivost, „Lidová demokracie“ 29.7.1993, popřípadě M. C. Putna, My posledni křestané - hněvivé eseje a vlídné kritiky, Praha 1994, s. 209.

11 S. Richterová, Otázka Boha ve světě bez Boha, „Literární noviny“ 1991, č. 13 (2), s. 5 , přetištěno in: eadem, Ticho a smích. Studie z české literatury, Praha 1997, s. 5. 
ovšem je také pokleslou, čistě materiální analogií myšlenky Boha, který je Alfou a Omegou. Popřel Boha, ale snaží se o jeho místo ${ }^{12}$.

Jinak řečeno: Kunderovo antropocentrické, tudíž nutně pesimistické pojetí nesmrtelnosti je pro křest’anskou teologii a z ní vycházející názory o životě věčném zákonitě zcela nepřijatelné.

Zhruba od druhé poloviny 90 . let 20. století se čeští prozaici střední a mladší generace stále výrazněji přiklánějí k takzvaným akčním žánrům. Motivy násilných (nejednou hrůzných) smrtí, odhalování jejich tajemství pak spoluvytvářejí tematické plány próz třeba Milana Kočího (narozen 1967) Trokadero (1997), Romana Ludvy (narozen 1966) Smrt a křeslo (1996), Žena sedmi klíču (1998), Jezdci pod slunečnikem (1999), Miloše Urbana (narozen 1967) Sedmikosteli (1999), Michaela (2004), Martina Komárka Smrtáci (2000), Ireny Douskové (narozena 1964) Někdo s nožem (2000), postavám profesionálních zabijáků jsou přisuzovány důležité role, viz Ludvovy Jezdce nebo román Bohuslava Vaňka Úvalského (narozen 1970) Zabrisky (1999), a koneckonců i v této souvislosti možno znovu připomenout Komárkovy Smrtáky. Nutno konstatovat, že thrillerové a hororové momenty, témata zla a jeho projevů, motivy násilného sprovodění lidské či jiné bytosti ze světa jsou využity především jako dobrodružné či dramatizující motivy. Což ovšem neplatí o Ireně Douskové a její novele Někdo s nožem. Náhodné zastřelení hlavní postavy zde pointuje varování, jak všudypřítomná agresivita a surovost, popř́ípadě strach před nimi deformují, někdy i definitivně likvidují lidské životy.

Předčasně zesnulá autorka Hana Andronikova (1967-2011) ve své poslední próze nazvané Nebe nemá dno (2010) vsadila na rozdíl od předchozích prací na autopsii. Děj lokalizovala do amazonského pralesa, nevadské pouště a Česka. Pokus zvládnout fatální onemocnění jinak než běžnými medicínskými prostředky přivádí vypravěčku na cesty, přičemž putování po světě získává paralelu ve výpravě do vlastního nitra, jeho nejskrytějších zákoutí. Dochází rovněž k prolínání reálných vjemů se snovými vizemi a mystickými prožitky, jsou prověřovány osobní (člověčí) možnosti a schopnosti. Strach a nejistota vyvolaná akutní hrozbou vlastního konce je kompenzována bezvýhradným přijetím této možnosti, smířením se s ní a schopností oprostit se od starostí, schopností radostného prožitku a potěšující hry, ztráty jsou výzvou k transformaci.

Vše je sdělováno bez sentimentu (respektive: se sentimentem je tu velmi osobitě nakládáno), výpovědní mozaiku skládají až úsečné, syrové deníkové zápisky a záznamy stavů změněného vědomí, sarkastický černý humor střídají lyrické básnivé pasáže. Nebe nemá dno je kniha vyznačující se mnohostí valérů, barevných, tvarových, chutových i zvukových.

Skutečnost, že mortální tematika zaujímala ve slovenské próze po roce 1989 významnou pozici, ozřejmuje už neúplný výčet takto inspirovaných děl i jejich

${ }^{12}$ Ibidem, s. 6. 
autorů: Rudolf Sloboda (1938-1995) Pamäti (1996) ${ }^{13}$, Václav Pankovčín (19681999) Bude to pekný pohreb (1997), Dušan Mitana (narozen 1946) Môj rodný cintorín (2000), Jana Beňová (narozena 1974) Plán odprevádzania (Café Hyena) (2008), Stanislav Rakús (narozen 1940) Telegram (2009), Monika Kompaníková (narozena 1979) Piata lod' (2010), Svetlana Žuchová (narozena 1976) Obrazy zo života M. (2013), Richard Pupala (narozen 1972) Návštevy (2014), Veronika Šikulová (narozena 1967) Medzerový plod (2014), Ondrej Štefánik (narozen 1978) Som Paula (2016) ad. Problematika literárního ztvárnění smrti se navíc objevila minimálně ve dvou studiích slovenských literárních vědců, konkrétně Vincenta Šabíka Podoba smrti v slovenskej postmodernej próze (1997) a Marty Součkové O smrti a/v literatúre alebo Čo práve čitaš, smrt? (2014).

$\mathrm{Z}$ řady polistopadových slovenských próz tematizujících smrt a záležitosti s ní související se následně podrobněji zaměřím pouze na tři tituly. Jedním z důvodů je mé přesvědčení, že patří mezi nejzdařilejší z dotyčné množiny, dalším pak fakt, že typologicky rezonují s některými př́stupy či druhy zpracování mortální a postmortální problematiky, které byly výše identifikovány a charakterizovány jako př́íznačné při reflexi české prozaické tvorby nedávných let.

První z takto vybraných prozaických knih vydal Marek Vadas (narozen 1971), konkrétně to byla povídková sbírka Prečo sa smrtka smeje (2003) ${ }^{14}$. Odpověd' na titulní otázku je jasná hned po přečtení několika textů (a vlastně možná už před začátkem četby). Smrt má totiž koneckonců vždycky navrch, nikdo a nic jí neuteče. A to vzpouzení se, marná snaha uniknout vlastnímu konci (nebo jej aspon̆ za jakoukoliv cenu oddálit), může být pro pozorovatele, který, takř́íkajíc „má svý jistý“ docela zábavné. Tuto prózu považuji za typologicky př́íbuznou těm českým dílům, které se soustředí na hry či zápasy se smrtí (Hodrová, Komárek ad.).

Vadas ve svých povídkách (mnohdy spíše črtách, etudách) prezentuje vskutku různorodou a rozsáhlou paletu odchodů ze života, přičemž způsobem podání akcentuje jejich absurditu, podivnost, neuvěritelnost. Ta pravá hrůza se však dostaví ve chvíli, kdy si uvědomíme, že autor se v podstatě nepohybuje v oblasti zvrácené fantazie, jak by se snad mohlo na první pohled zdát, ale jen mírně modifikuje každodenní mediální zpravodajství přetékající násilnostmi a tragédiemi. Viz povídku Dedina s dvoma puškami, v níž se výletník, libující si v idylické atmosfére vesnické hospůdky, stává svědkem střelby štamgastů na školačky vracející se domů. Tady nejde $\mathrm{v}$ zásadě o nic jiného, jak odhalí i méně bdělý a nepř́lilš soustavný publicistický konzument, než o transpozici incidentů v amerických a nejen amerických — školních zařízeních. Ani šokující snadnost, vynalézavost či bezohlednost, s jakou se některé postavy podílejí na likvidaci jiných, aniž by si připustily, že by snad dělaly něco zlého, odsouzeníhodného (Na prechádzke), není bohužel vůbec záležitost tvůrčí fikce.

13 Smrt patřila k zásadním tématům téměř v celé jeho tvorbě.

${ }^{14}$ Smrt v africkém prostředí a jeho mýtech je součástí tematického plánu další Vadasovy povídkové knihy Liečitel' (2006). 
Vadasova záliba v tajemnu, v hororové atmosfére je více než zjevná. Manifestuje ji například i využíváním a variováním, dalo by se říci, kanonických námětů. Konkrétně v povídce Arne hladá fotografie útočí zabijáčtí ptáci podobně, jako tomu bylo v kultovním filmovém hororu Ptáci Alfreda Hitchcocka. Předsmrtné zmítání jejich obětí pak vytváŕí v obilných polích legendární kruhy a obrazce.

Leitmotivem Vadasovy knihy jsou děsivé, zlé sny. Př́ikladná je v tomto směru úvodní povídka, ve které autor konfrontuje lidské individuum s řadou malérů, neprŕijemností, větších či menších osobních proher a tragédií. Takto vysílenému, na existenční hranici se ocitnuvšímu jedinci se pak ve chvíli, kdy nad ránem konečně zavře oči, „začne snívat’ naozaj zlý sen!“‘15.

Padlo-li tu jméno Alfred Hitchcocka, nutno konstatovat, že vedle tohoto filmového mága by mohli a měli být jmenováni i další Vadasovi předchůdci a inspirátoři, jako např́íklad Hieronymus Bosch, Edgar Allan Poe, ale též Franz Kafka, či Daniił Charms. Kafkovská atmosféra by se dala krájet v povídce Poštár neklope, jeho „obludný kolos beznádeje“ ${ }^{“ 16}$ se pak vyvalí z prózy Cudzinec. Charmsovský černý humor a groteskní prvky na nás zase dýchnou v povídkách Št’astie či $O$ voňavom chlapíkovi.

Vadas často pracuje s jistým schématem, jehož součástí je postižený či jinak asociální jedinec, nacházející se obvykle v baru, hospodě a tak podobně. Tato postava musí být posléze pokud možno co nejkurióznějším způsobem zlikvidována. Naštěstí toto schéma, respektive kombinační hra, v níž se základními pravidly stávají schválnost a krkolomnost, není autorem aplikována důsledně a dejme tomu v povídkách Michael Jackson sa ide ženit, popřípadě Šimon vylieza z krčmy len, ked' je pekne Vadas prokazuje, že se umí obejít i bez křečovité a násilné absurdizace významového vyznění textu a zároveň v něm kondenzovaně, nejednou s využitím realistického detailu, plasticky a sugestivně dokáže vystihnout tragikomický charakter lidského osudu.

Peter Macsovszky (narozen 1966), velmi plodný slovenský spisovatel, který až nezř́zeně experimentuje i provokuje, vydal svou prózu Mykat' kostlivcami (2010) vlastně cestou do Brazílie, kde v poslední době žije a tvoří. Jmenovaná próza vznikla, když pobýval v Amsterdamu, a tématu cizince v nevlastním prostředí v ní prrísluší významná pozice. Macsovszkého próza výrazně experimentálním a v mnohém ohledu subverzivním způsobem traktuje a reflektuje především problémy a jevy spojené konstantně s lidským životem, k čemuž funkčně využívá i cizokrajných kulis, přesněji konfrontace a komparace ciziny a domova. Budiž zdůrazněno, že na rozdíl od př́ípadů, kdy motivace postav k opuštění (či opakovanému opouštění) domova a dlouhodobějšímu nebo trvalému pobývání v cizině má své důvody politické či ekonomické, tedy sociální, hrají u Macsovszkého hlavní roli motivy privátní, ryze individuální, což umocňuje existenciální vyznění jeho prozaické výpovědi. To podtrhují rovněž leitmotivy, s nimiž si Macsovszky

\footnotetext{
${ }^{15}$ M. Vadas, Prečo sa smrtka smeje, Bratislava 2003, s. 6.

16 Ibidem, s. 44.
} 
dovedně a důmyslně pohrává. Patř́ $\mathrm{k}$ nim např́klad otázka, co $\mathrm{z}$ nás po smrti vskutku zůstane, která mimo jiné permanentně rezonuje v Kunderově Nesmrtelnosti i dalších jeho knihách. Macsovszkého odpověd' je příznačně mrazivá až sarkastická a prolíná jí také motiv očisty, respektive katarze pojaté jako zbavení se „masa“ hříchů a poživačnosti, problematických skutků, trápení a tak podobně: „Nakoniec z nás všetkých zostanú iba kostlivci. Chvalabohu, že kostlivci, aspoň niečo očistené "17. Ještě dodám, že tento nezpochybnitelný odkaz budoucím je v textu opakovaně připomínán také prostřednictvím kosterní grafiky José Guadalupe Posady, tzv. cavaleras, které jsou založeny na pojetí celého lidského života jako permanentního danse macabre, a které Macsovszkého knihu také ilustrují.

Jeden z nejuznávanějších slovenských literátů Pavel Vilikovský (narozen 1941) prožívá v posledních letech mimořádně plodné období. Vilikovského próza Letmý sneh (2014) je rozčleněna do pěti tematicky specifikovaných linií. Všechny linie a segmenty propojuje vypravěč, který se $\mathrm{v}$ ich-formě zabývá primárně problémy sebepoznání a sebeidentifikace, především v souvislosti s možnostmi a limity pojmenování. V další linii pak reflektuje ontologickou problematiku, klade si otázky o vztahu duše a těla, o rozdílu mezi tvorem a bytostí, a o kritériích určujících, kdo (co) patří do které kategorie, opakovaně se vrací tázání po smyslu našeho počínání. Ze třetí linie mimo jiné vzešel název prózy, jejím společným jmenovatelem jsou totiž laviny a kromě encyklopedických definic tohoto fenoménu jsou v ní zprostředkovány lavinovité ataky nejrůznějšího původu, kterým je během života vystavováno v současné civilizované společnosti lidské individuum, a to včetně onoho závalu definitivního, likvidujícího každou existenci. Čtvrtou linii si přisvojilo vypravěčovo nevlastní jednovaječné dvojče, pragmaticky a racionálně vystupující jazykovědec Štefan Kováč, který od bádání o bilabiálních konsonantech v řeči amerických indiánů kmene Menominiů přejde, motivován dobovou společenskou objednávkou, k projektu pojmenovanému Fonetická expresívnost' reči ako prejav vyspelého národného jazykového cítenia a charakteru. Autorova hravost signalizovaná už názvem prózy graduje právě v brilantních rozpravách mezi Čimborazkou (to je nové jméno, kterým se vypravěč-samozvanec nazývá) a Štefanem Kováčem na různorodá témata, od ženských zadků přes nejrůznější transcendentální ${ }^{18}$ pojetí a systémy (včetně jógy a zen buddhismu) až k jazykové vybavenosti průměrného Slováka. V páté linii sledujeme, jak vypravěč bojuje a vyrovnává se s faktem, že v důsledku onemocnění Pickovou chorobou jeho manželka Magdaléna ztrácí vlastní identitu, pamět', vůli, city, prostě vše, co považujeme za projevy a př́iznaky duševního života, a mění se z živoucí bytosti na vegetujícího tvora.

Na závěrečných deseti stránkách Vilikovského prózy se jednotlivé linie komplementárně prolnou. Vypravěč se zde definitivně, po marném pokusu zacpat díry

${ }^{17}$ P. Macsovszky, Mykat' kostlivcami, Bratislava 2010, s. 109.

${ }^{18}$ Návrat transcendentna do slovenských próz zmiňuje Vincent Šabík ve své studii nazvané Podoba smrti v slovenskej postmodernej próze, kterou inspirovalo hlavně posmrtně vydané dílo Rudolfa Slobody Pamäti (Bratislava 1996). Šabíkův text vyšel v publikaci Od moderny k postmoderne roku 1997 v Nitře. 
ve své bytosti obžerským tahem po bratislavských hospodách, rozchází s nevlastním jednovaječným dvojčetem Štefanem Kováčem ${ }^{19}$ a jde navštívit svou manželku v psychiatrické léčebně. Ona však, chorobou zbavená veškerých společných zážitků a prožitků i celé své identity, jej nepoznává a podává mu ruku se slovy: „Som rada, že vás spoznávam, pán doktor“ ${ }^{\prime 20}$. Protagonista a vypravěč se v následné reakci dobrovolně vlastně zříká téhož, oč manželku připravila nemoc, a představuje se svým novým jménem, demonstrujícím novou totožnost: „Čimborazka, povedal som a podal som jej ruku“21.

Vilikovského Letmý sneh vnímám jako jistou paralelu zachycení fatálního postupného odcházení ze života, opouštění pozemské individuality, nezvratného procesu rozkladu lidské existence způsobeného chorobou, jak ho realizovala a prezentovala nedlouho před slovenským autorem česká spisovatelka Hana Andronikova ve svém posledním díle Nebe nemá dno.

Rozhodně nelze tvrdit, že by smrt a záležitosti s ní související byly za předchozího režimu pro české a slovenské spisovatele nějakým tabu, nicméně ideologické podloží tehdejší společnosti preferovalo optimističtější látky. Snad také proto lze po zásadní změně politických a sociálních poměrů v české i slovenské literatuře registrovat konjunkturu slovesných děl s mortální a postmortální tematikou. Patří k nim hlavně díla zprostředkovávající odvěké zápasy a někdy i hry, pohrávání si se smrtí (viz prózy D. Hodrové, M. Komárka, M. Vadase), popřípadě romány aktuálně reflektující fenomén nesmrtelnosti (např́íklad Kunderova Nesmrtelnost, Macsovszkého Mykat'kostlivcami), anebo texty tematizující proces odcházení do nebytí důsledkem nemoci (H. Andronikova Nebe nemá dno, P. Vilikovský Letmý sneh). V daných souvislostech nemá valného smyslu pokoušet se o nějaké syntetizující závěry. Nicméně jednoho se dopustím: Také české a slovenské prózy vypravující se do Thanotovy říše a vyprávějící o ní možno bez rozpaků použít jako argumenty stvrzující, že pro obě zmíněné národní literatury představuje polistopadový čas mimořádně plodné období.

\section{Bibliografie}

Hodrová D., Kukly, Praha 1991.

Hodrová D., Podoboji, Praha 1991.

Fronková K., Pavel Vilikovský - Letmý sneh. Recenzia, http://emsjeradio.wixsite.com/emsjeradio/ single-post/2015/07/06/Pavel-Vilikovsk\%C3\%BD-\%E2\%80\%93-Letm\%C3\%BD-snehRecenzia.

Koudelka P., Peřička, peřička, Praha 1992.

Křepelka K., Přiliš smrtelná nesmrtelnost, „Proglas“ 1993, č. 9-10 (4).

Kundera M., Nesmrtelnost, Brno 1993.

Macsovszky P., Mykat' kostlivcami, Bratislava 2010.

${ }^{19} \mathrm{~S}$ ohledem na tápání např. recenzentky Karin Fronkové považuji za užitečné explicitně konstatovat: Štefan Kováč JE racionální a pragmatickou součástí vypravěčova JÁ.

${ }^{20}$ P. Vilikovský, Letmý sneh, Bratislava 2014, s. 143.

${ }^{21}$ Ibidem. 
Putna M. C., My posledni krest’ané — hněvivé eseje a vlídné kritiky, Praha 1994.

Richterová S., Otázka Boha ve světě bez Boha, „Literární noviny“ 1991, č. 13 (2); přetištěno in: eadem, Ticho a smich. Studie z české literatury, Praha 1997.

Součková M., O smrti a/v literatúre alebo Čo práve čitaš, smrt??, „Nový život” 2014, č. 5-6 (64).

Šabík V., Podoba smrti v slovenskej postmodernej próze, [in:] Od moderny k postmoderne, eds. M. T. Žilka, Nitra 1997.

Švanda P., Nesmrtelnost a nedůvěřivost, „Lidová demokracie“ 29.7.1993.

Vadas M., Prečo sa smrtka smeje, Bratislava 2003.

Vilikovský P., Letmý sneh, Bratislava 2014.

\section{Battles and dancing with death in the mirror of immortality (in Czech and Slovak prose written after November 1989)}

\section{Summary}

Thematization of human mortality has often been present in Czech and Slovak prosaic works written after 1989. This article presents (and sometimes also analyses and interprets in detail) these works. The author, for example, points out that in Trýznivé město, a trilogy written by D. Hodrová, people try to play games with death, or to struggle with it. In the novels written by P. Koudelka (Peřička, perrička) or M. Kundera (Nesmrtelnost/Immortality) the phenomenon of immortality is reflected. Since the 1990s, many younger Czech writers have been tending towards the so-called action genres and that is why depictions of violent death appear in their books more frequently. H. Andronikova vividly depicts a man's fatal fight with a mortal disease. Out of Slovak prosaic works dealing with the issue of mortality, the author of the article thoroughly analyzes prose by M. Vadas (Prečo sa smrtka smeje), P. Macsovský (Mykat' kostlivcami) and P. Vilikovský (Letmý sneh). The author concludes that most of the novels reflecting the phenomenon of immortality have significantly enriched national literatures of both countries.

Keywords: typological overview, interpretative analysis, mortal themes, Czech and Slovak prose after 1989

\section{Дуэли и танцы со смертью в зеркале бессмертия (в чешской и словацкой прозе после ноябрьских событий)}

Резюме

Тема человеческого бессмертия часто встречается в чешской и словацкой прозе после 1989 г. В статье представлен обзор, анализ и интерпретация произведений, в которых писатели обращаются к исследуемой теме. В трилогии Город мучений (Trýznivé mésto) Д. Годровой герои пытаются играть со смертью или бороться с ней. В романах П. Коуделки Перо, nepo (Peřička, peřička) и М. Кундеры Бессмертие (Nesmrtelnost) проанализирован феномен бессмертия. В 1990-х годы многие молодые чешские писатели (например, Р. Лудва и М. Ур- 
бан) обращаются к приключенческим жанрам, в их произведениях прослеживается мотив насильственной смерти. В творчестве Г. Андроникова показано столкновение человека со смертельной болезнью. Темы смерти в словацкой прозе анализируется на материале произведений Почему Смерть смеётся (Prečo sa smrtka smeje) М. Вадаса, Трясущийся скелет (Mykat’ kostlivcami) П. Мачовского и Тающий снег (Letmý sneh) П. Виликовского.

Ключевые слова: типологический обзор, интерпретационный анализ, мортальная тематика, чешская и словацкая проза после 1989 года 